\title{
INTERPLAY OF SOCIAL REPRESENTATIONS, TRAUMA AND VICTIMIZATION IN INTRACTABLE CONFLICTS: THE CASE OF THE CYPRUS CONFLICT
}

\author{
Cristiana Lavinia Bădulescu \\ The National University of Political Studies and Public Administration \\ Bucharest, Romania \\ lavinia_Ip@yahoo.com
}

\begin{abstract}
A bstract
Intractable conflicts are conflicts that persist over a long period of time, resist various attempts of resolution, and present sporadic episodes of violence juxtaposed with periods of relative calm. Also, they contain a large share of psychosocial factors which lend to their uniqueness while also adding to their complexity. The Cypriot conflict is such a conflict. It has been on the agenda of the international community for over four decades, it has gone through a number of occasional violent episodes that fluctuated in frequency and intensity, and has resisted various peace mediation efforts. As a result, the conflicting parties remained locked in an adversarial relationship and fixed in terms of fundamental grievances. This paper aims to explore the interplay of social representations, trauma and victimization in the Cyprus conflict, and their implications on the prospects for its further settlement. Specifically, using discourse analysis as a research method, this paper analyses both the GreekCypriot and Turkish-Cypriot official discourse during 1983-2012 in order to see how the two parties represent the conflict, and whether past trauma and victimization influence their social representations. Close attention to the key themes emerging from the two parties' official discourse helps to deepen understanding of the role and effect social representations, trauma and victimization play in the perpetuation of the Cyprus conflict.
\end{abstract}




\section{Keywords}

Conflict resolution, Cyprus, intractable conflicts, social representations, trauma, victimization

\section{INTRODUCTION}

Intractable conflicts are known under different labels such as deep-rooted conflicts (Burton 1987), enduring rivalries (Goertz and Diehl 1993), protracted conflicts (Azar 1990), malignant conflicts (Deutsch 1985). Generally, intractable conflicts are defined as being conflicts persisting over a long period of time, resisting various attempts at resolution, and presenting sporadic episodes of violence juxtaposed with periods of relative calm (Coleman 2006). The conflicts between Israel and Palestine, Armenia and Azerbaijan over Nagorno-Karabakh, Greek Cypriots and Turkish Cypriots, Georgia and the breakaway regions of Abkhazia and South Ossetia, India and Pakistan over Kashmir region, are cases in point.

In the literature, intractable conflicts are described as possessing a number of well-defined characteristics that underline their essence. For instance, Louis Kriesberg (2005, 66-68) and Daniel Bar-Tal (2007, 1432-1433) point out the following particular features that characterize intractable conflicts:

1. They are protracted. Intractable conflicts persist for a long time, at least one generation. Various and failed resolution attempts undertaken over a long period of time lead to the accumulation by the parties of animosity, grievances, negative feelings, prejudice.

2. They are perceived as irreconcilable. Parties involved in intractable conflicts perceive their goals as irreconcilable. Each side holds to its own goals, viewing them as essential for own survival; neither side sees the possibility of making concessions and resolve the conflict peacefully.

3. They involve vast investments. Parties in intractable conflicts make vast military, economic and psychological investments which later have repercussions on the resolution attempts. 
4. They are violent. Intractable conflicts involve outbreaks of violence which alternate in intensity and frequency, are associated with destruction, grave human rights violations, atrocities, refugees and internally displaced persons (IDPs), and cause traumatic consequences for the members of the societies involved in the conflict.

5. They are perceived as being of zero sum nature. Each party considers any gain recorded by its opponent as its own loss, and any loss suffered by its opponent as its own gain.

6. They are total. Intractable conflicts are perceived by the parties concerned as involving needs and values that are fundamental for their existence or survival. Therefore, intractable conflicts address a multitude of issues such as territory, resources, identity, economy, religion, etc.

7. They are central. Members of the societies involved in an intractable conflict are preoccupied constantly and continuously with it. This preoccupation reflects its centrality both in the lives of the individual group members and in public life, for instance in the media or the speeches of the leaders. The conflict is at the top of the public agenda and salient in debates.

Hence, this type of protracted, violent and destructive conflicts has serious implications for the societies involved, both at micro-, mid-, macro-structural level. For instance, at micro level, individuals present psychological wounds and a deep sense of injustice, victimization, humiliation; at mid-level, the groups and the institutions to which individuals belong operate on a dysfunctional pattern; at macro level, the concerned societies are refractory to any signal of change, construction in the meaning of reconciliation, of social progress (Bar-Tal, Halperin and Pliskin, 2014).

Intractable conflicts are differentiated by the presence of a large share of psychosocial factors. These factors distinguish intractable conflicts from other type of conflicts and ensure their uniqueness (Bar-Tal 2013). Psychosocial factors such as traumas, stereotypes, emotions, belief systems, victimization, historical grievances, social representations, accompany the internal, less visible sides of intractable conflicts. In this paper, I focus on social representations (about the conflict), trauma and victimization (both at the collective level). I hypothesize that past collective trauma and victimization reflected in the parties' social 
representations about the Cyprus conflict determines its perpetuation. Two research questions were used to guide and develop the hypothesis and the research design of this article:

a) What is the relationship between social representations, trauma and victimization in the Cyprus conflict?

b) What are the implications of social representations, trauma and victimization on the prospects for the further settlement of the Cyprus conflict? The paper is structured as follows. Firstly, I start with a literature review of the key concepts used in the development of the argument. Then I move to the presentation of the Cyprus conflict by providing some background and review of settlements efforts. Finally, I analyse the Greek Cypriot and Turkish Cypriot official discourse in order to see how the two sides represent the conflict, and whether past trauma and victimization influence the forming of these social representations.

\section{METHODOLOGY}

From a methodological perspective, I use discourse analysis applied on the official discourse of the Greek Cypriots (henceforth GCs) and Turkish Cypriots (henceforth TCs) leaders, and following two dimensions:

I. the representation of the conflict (how GCs and TCs represent the conflict)

II. the temporal and contextual framing of the representations about the conflict (the periods and the social contexts that GCs and TCs make reference to) The period for the analysis of the official discourse is 1983 - 2012. The time period marks the strongest efforts of the United Nations Secretary General, including the personal involvement of Pérez de Cuéllar, Boutros Boutros-Ghali, Kofi Annan and Ban Ki-moon, to negotiate and find a solution to the Cyprus conflict. In total, I have selected 14 official discourses belonging to the leaders in 
office during the selected period of study. ${ }^{1}$ These comprise of inaugural speeches, speeches at UN sessions and at various national and international meetings, official letters, interviews, and were collected from government websites, UN website and mass-media.

\section{LITERATURE REVIEW}

Intractable conflicts are prolonged conflicts leaving room for the infiltration of psychological wounds, grievances, and animosity between the members of the societies involved. As mentioned above, they involve vicious cycles of violence and a large range of psychosocial factors that contributes to their uniqueness. In this section, I define and explain key concepts such as social representations, trauma and victimization, and interrelated psychosocial factors with special significance in intractable conflicts.

Social representations are "a set of concepts, statements and explanations originating in daily life in the course of interindividual communications. They are the equivalent in our society, of the myths and belief systems in traditional societies; they might even be said, the contemporary version of common sense" (Moscovici 1981, 181 quoted in BarTal 2014, 5.2-5.3). According to this definition, social representations are collectively shared concepts and images constructed in language and infused with meaning. They constitute the constructed shared social reality of a group and are held individually by the majority of its members, as well as reflected in public discourse on an individual and collective level, for instance in mass-media (Bar-Tal 2014, 5.3).

The studies centred on social representations in the context of intractable conflicts have their basis in the field of social psychology. Scholars argue that in

${ }^{1}$ For the GC community, the leaders in office during 1983-2012 were: President Spyros Kyprianou (1983-1988), President Vassiliou (1988-1993), Glafcos Clerides (1993-1998 and 1998-2003), Tassos Papadopoulos (2003-2008) and Demetris Christofias (20082013). For the TC community, the leaders in office during 1983-2012 were: Rauf Denktash (1983-2005), Mehmet Ali Talat (2005-2010) and Dervish Eroglu (2010-2015). 
intractable conflicts, there are specific social-psychological processes, such as the formation of representations that the parties hold of each other and themselves, and of the conflict as such. These contain a strong emotional dimension and are central to intractable conflicts (Kelman 2007; Gross Stein 1996). The interactions of the social representations the parties have about the conflict they are involved in bolster distrust and dehumanization, reduce empathy and foster a win-lose mentality. Also, they are highly resistant to contradictory information or change (Fisher and Kelman 2011, 70-75). Furthermore, the parties of an intractable conflict tend to "demonize" each other (Hadjipavlou 2007, 350) and to assign its causes to the personal suffering and injustices perpetrated exclusively by the "foreign Other" (Hadjipavlou 2017, 213). Thus, the opposing party, the one perceived as being the enemy, becomes the main guilty person and solely responsible for the failure of individual tracts. Such features apply to the Cyprus conflict, as it will be shown later in the analysis.

Trauma is defined as a catastrophic stressor that was outside the range of everyday human experience (Friedman, 2016). When a traumatic experience is shared by a group of people it is called collective trauma. Collective trauma is defined as "a blow to the basic tissues of social life that damages the bonds attaching people together and impairs the prevailing sense of communality" (Erikson 1995, 184). "It consists of three primary elements: a "trauma" or wounding; the trauma is shared by a group of people, rather than an individually experienced; the trauma spans multiple generations, such that contemporary members of the affected group may experience trauma-related symptoms without having been present for the past traumatizing event(s)" (Mohatt et al. 2014, 128). It can be either man-made (war, genocide, etc.) or caused by natural disasters (tsunamis, storms, fires, etc.). My focus in this paper is on man-made collective trauma, as occur in armed conflicts for instance. When a trauma transforms itself into a collective one, the societies involved maintain the mental representation of the traumatic event together with the shared feelings of loss and pain associated with it (Volkan 1998). They internalize the collective trauma and transmit it across generations through narratives with a strong emotional content which serve to keep the trauma alive, thus reinforcing the original sense of assault and loss (Tint 2010, 247). Conflict resolution scholars point out the link between collective trauma and the 
intractability of the conflict. The violent and traumatic experiences lived in the past by the parties involved in an intractable conflict are encoded in their collective memory, which maintains a sense of a state of offence and of a past injustice throughout generations, and become part of their identity (Brewer 2011). When such traumas are engraved in identity, they end up becoming the central core of the collective narratives regarding the conflict (Wertsch and Roediger 2008; Hunter and Stewart 2015). In addition, they determine emotional problems to become just as important as the real problems that are at play such as the dispute over a specific territory (Noor et al. 2012).

The parties involved in an intractable conflict that have gone through violent traumatic experiences, either directly or indirectly, develop a sense of victimization at the collective level (Staub and Bar-Tal 2003; Bar-Tal et al. 2009). Victimization at the collective level is defined as a "mindset shared by group members that results from a perceived intentional harm with severe and lasting consequences inflicted on a collective by another group or groups, a harm that is viewed as undeserved, unjust and immoral, and one that the group was not able to prevent" (Bar-Tal et al. 2009, 238). Research points out that under the influence of suffered traumas, a group focuses only on its own sufferings and is less inclined to empathise with the victims of the other group. In the literature, this phenomenon is called "the egoism of victimization" (Mack 1990) and its often encountered in intractable conflicts.

Trauma and victimization at the collective level support antagonisms and deep divisions between the parties of an intractable conflict. As I will show later in the analysis, this is the case of the Cyprus conflict too.

\section{BACKGROUND TO THE CYPRUS CONFLICT}

The island republic of Cyprus, comprising two major ethnic communities, namely the GCs and the TCs, was under the Ottoman rule from 1571 until 1878. In 1878, Great Britain assumed control of Cyprus from the Ottomans, and became officially a British colony from 1925 until its independence in 1960. The British colonial period corresponded with the rise of nationalism in Cyprus. 
Thus, when the struggle against the British started in 1955, GCs and TCs aspired at different futures for the island: GCs favoured enosis, the union of Cyprus with Greece, while TCs envisioned taksim, the partition of the island (Papadakis, Peristianis and Welz 2006, 2).

A compromise settlement was reached in 1959 by Britain, Greece, and Turkey with the London-Zurich Agreements that granted Cyprus its independence. At independence, the constitution of Cyprus defined power-sharing arrangements between the two main groups. It required a GC president and a TC vice president, each elected by his own community and with veto power over decisions. A cabinet of ministers was composed of seven GCs and three TCs, and the same ratio was maintained in Parliament and all branches of the civil service. Simultaneously, a Treaty of Guarantee signed by Britain, Greece, and Turkey gave all three powers the right to unilaterally intervene as an extreme measure to protect the security interests of Cyprus. Additionally, a Treaty of Alliance among Cyprus, Greece, and Turkey provided 950-man Greek and 650-man Turkish soldiers to help defend the island (Anastasiou 2007, 77-78). However, the 1960 settlement did not pay attention to the two communities" "local realities and socialpsychological needs and concerns. Instead, the constitutional provisions granted in 1960 intensified and institutionalized ethnic/identity differences and gave rise to further mistrust and antagonism and an unwillingness to express loyalty to the newly established state" (Hadjipavlou-Trigeorgis and Trigeorgis 1993, 343).

The newly created republic enjoyed some fragile stability between 1960 and 1963. After President Makarios proposed amendments to the constitution, the so-called "13 Points" that favoured the majority of the GCs, relations between the two communities deteriorated and further led to inter-communal clashes in 1963 and 1964 that caused much suffering and insecurity, especially for TCs (HadjipavlouTrigeorgis and Trigeorgis 1993, 344). Several hundred people were killed, many others were wounded and kidnapped. As a consequence, the TC leadership withdrew from the government and began to administer their own affairs. Also, TCs started to geographically separate themselves from the GCs and relocate into enclaves limited to three percent of the island (Volkan 2008, 96). Some 25,000 TCs and 500 GCs had become IDPs. Furthermore, even if more than $50 \%$ of 
villages were mixed in 1891, by 1970 this figure dropped to less than 10\% (Fisher 2001, 310).

Following the crisis of 1963, the two parties and the guarantor powers (Britain, Greece, and Turkey) met in London to find a solution, but without any results. The United Nations Security Council unanimously adopted in 1964 the Resolution 186 which recommended the establishment of a United Nations Peacekeeping force mandated to "use its best efforts to prevent a recurrence of fighting and, as necessary, to contribute to the maintenance and restoration of law and order and a return to normal conditions" (Resolution 186 1964, 3). The United Nations Peacekeeping Force in Cyprus (UNFICYP) became operational on March 27, 1964 and is still operational today.

In 1974, a Greek-junta coup against Makarios took place. The fighting also spread over the TC villages and enclaves. Turkey, citing the 1960 Treaty of Guarantee as a legal basis for its action, deployed its military forces and took control of more than one-third of the island (Morelli 2015, 1). The landing of the Turkish army on the northern part of Cyprus caused widespread dislocation. About 160000 GCs were forced to flee to the south thus creating massive refugee and property problems. "Subsequent to the ceasefire, an agreement on the voluntary regrouping of populations resulted in approximately 40000 TCs moving to the north, while the approximately $10000 \mathrm{GCs}$ left in the north were pressured to go south. Thus, the events of 1974, in which several thousand people were killed or went missing, had the effect of creating two homogenous ethnic zones on the island" (Fisher 2001, 311).

In February 1975, TCs declared their government the "Turkish Federated State of Cyprus" (TFSC). In 1983, the "Turkish Republic of Northern Cyprus" (TRNC) headed by Rauf Denktash - was self-proclaimed, but failed to gain recognition by the other countries except Turkey. Since 1974, the GC and TC communities on the island have remained physically separated by a demarcation line patrolled by United Nations troops. 


\section{SETTLEMENT EFFORTS. A REVIEW OF FAILURE}

The Cyprus conflict has been on the agenda of the international community for over five decades, but has resisted various settlement efforts. In this section, I will highlight the most important moments of the peace process that took place after the 1974 coup and until 2012.

One of the first important attempts to seek a settlement to the Cyprus conflict after the 1974 coup took place on January 27, 1977, when Makarios and Denktash, the two leaders of the two communities, met for the first time in fourteen years under the United Nations auspices for high-level talks. They agreed on four guidelines for an independent bicommunal federal republic, "the primary one being that the parties were seeking an independent, non-aligned, bicommunal federal republic. The other related to the territorial division not being strictly on the basis of population ratio, the freedoms of movement, settlement, and ownership for the GC being implemented with sensitivity to TC concerns, and the central government safeguarding the unity of the state while respecting its bicommunal character" (Fisher, 2001, 314-315). The guidelines, which were thought of as forming the basis for any further peace talks, were reaffirmed in 1979 during another round of United Nations-sponsored talks between Makarios' successor, President Spyros Kyprianou, and Rauf Denktash. The parties brought a refinement of the Makarios-Denktash guidelines which is labelled as the tenpoint agreement. In addition to accepting these guidelines, this agreement demanded the immediate resettlement of the GC area of Varosha and for the ultimate demilitarization of the island (Theophanous and Christou 2014, 80).

These two high-level agreements were meant to lay the foundations for subsequent successful intercommunal talks. However, the restarting of negotiations at the beginning of the 1980s revealed obvious disagreements between the parties, especially over the priority and the sequencing of items. For instance, between 1982 and 1991, the United Nations Secretary-General, Javier Pérez de Cuéllar, made several proposals to the leaders, including a Draft Framework Agreement in 1986 which foresaw the creation of an "independent, non-aligned, bi-communal state in Cyprus, but was more detailed than the 1977 agreement in that it began to define the federal government's powers." (Security 
Council Report 2008, 7). Nevertheless, the GC did not agree with this initiative because it did not address the withdrawal of the Turkish troops, not the repatriation of Turkish settlers (Security Council Report 2008, 7). Consequently, this settlement initiative failed.

Another important attempt of the United Nations to settle the Cyprus conflict took in 1992 when the new United Nations Secretary-General, Boutros-BoutrosGhali, starting from the work of his predecessor, introduced a document entitled "Set of Ideas on an Overall Framework Agreement on Cyprus." The ideas envisaged two federated states with identical powers to safeguard the cultural identity and ensure the political equality of each community. The framework stipulated the division of powers between the federated states and the federal government, and a bicameral legislation with a federal executive to ensure representation from each community. Also, the 1960 treaties were reaffirmed, and the questions of territorial adjustment and the three freedoms (movement, settlement, and ownership) were also addressed. However, the TC side disagreed with several points of the initiative, including the questions of sovereignty, return of displaced persons and the nature of territorial arrangements (Fisher 2001, 316). Hence, the UN's proposal, yet again, failed.

The same happened with the next UN's initiative of confidence-building measures introduced in 1993, which had at its centre the reopening of the Nicosia International Airport for the benefit of both communities and the opening of the Turkish-held area of Varosha to resettlement by Greek Cypriots with UN control. Differences existed on these measures from both sides, but especially from the Turkish Cypriot one which insisted that the northern part of Varosha would have to remain within its control and that all embargoes be lifted in Northern Cyprus (Michael 2009, 134).

It was not until in 2002 when the negotiations for finding a solution to the Cyprus conflict seemed to renew hopes for a settlement with the so-called Annan Plan. This was introduced by the United Nations Secretary-General, Kofi Annan, comprised of "182 pages of main articles and finalized laws, 9,000 pages of draft laws and treaties, and was the result of more than 300 meetings" (Anastasiou 2007, 94-95). The Annan Plan proposed the creation of a bizonal, bicommunal federal republic based on the Swiss model. It called for the creation of the United Cyprus 
Republic, "an independent state in the form of an indissoluble partnership, with a federal government and two equal constituent states, the Greek Cypriot State and the Turkish Cypriot State" (Annan Plan 2004, 7). The federal government would participate in foreign and European Union relations while two politically equal component states would address much of the daily responsibilities of government in their respective communities (Morelli 2015, 3). After subsequently going through five major revisions to harmonize the demands of the parties, the final version of the Annan Plan was finalized on March 31, 2004, and submitted to simultaneous referenda on April 24, 2004. The results showed that the GC voters rejected the plan by a margin of three to one, while the TC voters accepted it by a margin of two to one (Report of the Secretary-General on his mission of good offices in Cyprus 2004, 1). After this failed attempt, the negotiations went into limbo for some time.

The official talks resumed again in 2008 when Demetris Christofias and Mehmet Ali Talat, the leaders of GC and TC communities, decided to start full-fledged negotiations under the good offices of the United Nations Secretary-General in order to find a solution to the Cyprus conflict. The talks were held on a regular basis and went well during the first 18 months until the differences in positions between the two leaders became obvious. Talat wanted to pursue negotiations on the basis of the old Annan Plan, while Christofias wanted to avoid bring it again into discussion. In January 2010, the United Nations Secretary-General, Ban Ki-moon, visited Cyprus, met with the two leaders and encouraged them to bring the negotiations to a successful conclusion. However, the talks seemed to reach a deadlock as the last formal meeting session between Christofias and Talat concluded in March 30, 2010 with no new developments (Morelli 2015, 3-4).

A new stage in the negotiation process between the GC and TC communities reopened in May 2010 under the auspices of the United Nations SecretaryGeneral's special advisor on Cyprus, Alexander Downer. Amid a lack of progress in the negotiations, Dervis Eroglu, who succeeded Mehmet Ali Talat as leader of the TC community, declared in October 2010 that as time passes, the will of the two communities to coexist was decreasing (Küçükkoşum 2010). The next period of peace talks covered several meetings between United Nations Secretary-General, Ban Ki-moon, and the two leaders, Christofias and Eroglu. 
The first one took place on November 18, 2010 in New York. In a statement after the meeting, Ban Ki-moon said that the two leaders expressed their commitment to work more quickly and decisively to find a common ground on the core issues of the dossier (Morris 2010). The second meeting between Ban Ki-moon, Christofias and Eroglu was held in Geneva on January 26, 2011, and did not bring any breakthrough in the negotiations (United Nations News Centre 2011). The third meeting between the three took place again in Geneva on July 7, 2011. This time the United Nations chief noted that progress has been too slow and that some important issues have remained unaddressed (United Nations News Centre 2011). The fourth tripartite meeting was held in New York on October 2011, but concluded without any new agreement to end the stalemate. Ban Kimoon declared that "there is still work to be done" and that he invited again the two leaders to meet in a similar format on January 2012 (United Nations News Centre 2011). They indeed met again in New York on 23-24 January 2012, but as in all the other previous meetings, this one ended as well without any agreement over the core issues of the conflict (United Nations News Centre 2012). Following these developments, the official negotiations were yet again halted.

The above moments of the peace process are indicative of the perpetuation pattern the Cyprus conflict has embarked on. Despite various attempts at finding a solution, either through direct negotiations between the leaders of the GC and TC communities or through the help of the United Nations, the Cyprus conflict is still unresolved. One retired United Nations official has described the official talks to settle this conflict as being "the most frustrating" ones and compared them with "the gyroscopic stabilizer on a ship in a storm. They go round and round and produce a certain stability, even if they do not produce forward motion." (Urquahart 1987, 259 quoted in Souter 1989, 76). As a result of the failure of the settlements efforts, the conflicting sides remained locked in an adversarial relationship and fixed in terms of fundamental grievances. 


\section{SOCIAL REPRESENTATIONS ABOUT CON FLICT}

\subsection{The representations that the GCs have about the Cyprus conflict}

For the analysis of the social representations that the GCs have about the Cyprus conflict, I selected the following official discourses at the level of the President: President Vassiliou's speech at the 47th session of the United Nations General Assembly (UNGA) in 1992, President Clerides' speech at the 54th session of the UNGA in 1999, President Papadopoulos' inaugural speech at the House of Representatives in 2003, President Papadopoulos' speech during an official visit to Greece in 2003, President Papadopoulos' speech at the 62nd session of the UNGA in 2007, President Christofias' speech at the ceremony of his investiture at the special session of the House of Representatives 2008, President Christofias' speeches at the 66th and 67th sessions of the UNGA in 2011 and 2012. In these official discourses, as compared to others, the Cyprus problem is addressed more broadly and elements pertaining to trauma, representation of the conflict and victimization intersect each other.

GCs represent the conflict in terms of "occupation", "invasion", "refugees", "missing persons", and "foreign aggression". The words that are used most often are "occupation" and "invasion", which are encountered several times within the same discourse, having as an effect the emphasising of the situation in which the GCs are found. This manner of conflict representation is linked with Turkey and the decision to intervene in 1974 in the support of the TCs, which added a third player to the conflict between the two communities. Thus, in their official discourses, the GCs highlight the international aspect that was acquired by the Cyprus conflict through Turkey's intervention from 1974, and the fact that Turkey is in fact the real perpetrator, the enemy in this conflict. From the GCs' perspective, the conflict started in 1974 and it is a matter of invasion and foreign occupation, beside a series of other elements that were caused, such as refugees, missing persons, enclaved persons, loss of territory. The speech of President Papadopoulos during the 62nd session of the UNGA in 2007 is explanative in this sense. According to him "the Cyprus issue, when stripped of niceties of diplomatic terminology, is a question of foreign aggression and continuing occupation of a significant part of a sovereign State, entailing enclaved and missing persons, refugees 
and massive and enduring violations of human rights". In the same speech, Papadopoulos adds that: "the Cyprus problem is not a derivate of bad community relations, but one of outside intervention." The same President Papadopoulos mentions, during an official visit to Greece, that "the crux of the Cyprus problem is the Turkish invasion and occupation." President Christofias clarifies this aspect as well. During a speech held at the 66th session of the UNGA in 2011, he emphasizes that "the essence of the Cyprus problem" is "first and foremost a problem of invasion and occupation, a problem of violation of international law and human rights of Cypriot citizens." The same President Christofias, still at the UNGA, but at the 67th session in 2012, raises again the problem of the 1974 Turkish invasion and of the consequences that it caused on the inhabitants of the island:

\begin{abstract}
"Cyprus still faces the consequences of foreign intervention and of the Turkish invasion and occupation. M ore than one third of the territory of my country is still under military occupation by Turkey... Y et Turkey, after invading Cyprus in 1974, continues to occupy, for 38 years, the northern part of the island, ... to violate human rights and fundamental freedoms of tens of thousands of displaced persons, including the usurpation of their property, the rights of the enclaved and the people who lost their loved ones and continue to search for them."
\end{abstract}

What can thus be noticed is the GCs' constant and continuous preoccupation toward the conflict. The fact that the Cyprus conflict is always inserted into the official discourse of the CGs denotes the importance of the subject within the public agenda and the attention that it is given at this level. Moreover, at the official level, the Cyprus conflict is represented as being an unprecedented tragedy in the history of the country: "In the course of its history, Cyprus has met with attacks, conquests, adventures. The difference with today's barbaric invader is that he came not only to grab, but also to stay on the island..." (President Papadopoulos' speech during an official visit to Greece in 2003). The social representations that the GCs have about the conflict are temporally and contextually framed in 1974, the year that marks Turkey's intervention in Cyprus. For the GCs, this moment and social context represent a collective trauma, which draws painful memories about the assault, the human and material losses they suffered, but also feelings of injustice. This episode is generally described by the GCs as "all hell breaking 
loose" (Volkan 2008, 96), a moment when many GCs became missing persons, were killed, captured or had to run from the violence's path and move in the southern part of the island in order to save their lives. In the selected official discourses of the GCs, the 1974 episode is often remembered in terms of ethnic cleansing. For instance, President Vassiliou, during his speech at the 47th session of the UNGA in 1992, emphasizes "the devastating effects of ethnic cleansing following the Turkish invasion of 1974" and the plight of the GCs who "were evicted from their ancestral homes and properties in order to create ethnically clean areas." During the speech from the 10th session of the UNGA in 1999, President Clerides also mentions "the ethnic cleansing Turkey practiced against Greek Cypriots, which resulted in 180,000 GCs becoming refugees in their own country", "the drama of the relatives of the $1600 \mathrm{GCs}$ missing since the invasion of Cyprus by Turkish forces in 1974" and "the many violations of human rights of the Greek Cypriots."

The above statements are also indicative of the pronounced feeling of being victimised that exists among the GCs. In the official discourses, GCs use frequently the words "to suffer" and "suffering". For instance, in 2011, during the 66th session of the UNGA, President Christofias begins his speech by drawing attention to the sufferings that his country was forced to go through: "The Republic of Cyprus has experienced violence and we still suffer from its consequences. It still suffers from the consequences of the illegal Turkish invasion of 1974 and the ongoing occupation. Thirty-seven later, the Republic of Cyprus [... ] still suffers from the occupation of a large part of its territory by the military forces of Turkey." President Vassiliou talks about the sufferings of the inhabitants of the island as well. According to him, the resolution of the Cyprus conflict will bring "an end to the forcible division of our country and the resulting suffering of so many, particularly of the families of the missing persons" (excerpt from President Vassiliou's speech at the 47th session of the UNGA, 1992). However, President Papadopoulos is the most direct on this issue. During his inaugural speech as president of Cyprus in 2003, he draws attention to the victim status of GCs stating that: "We first and foremost, the members of the Greek-Cypriot community, are anxious to reach a solution of the Cyprus Problem. We most of all care about a quick solution because it is we who as victims of a continuing invasion and occupation, want the immediate cessation of the tragedy of our country...". 
From the above excerpts, one can observe how the GCs attribute the causes of their sufferings to the "other", in this case to Turkey. For the GCs, the victimization appears because of Turkey, and not because of the TCs, given the 1974 traumatic experience. In fact, the TCs appear in the GC official discourses as being citizens of Cyprus, part of the same Cypriot people, and partners. For instance, in their speeches, Presidents Vassiliou and Christofias very often use phrases such as "the people of Cyprus, Turkish Cypriots and Greek Cypriots alike" or "our Turkish Cypriot compatriots" (Vassiliou's speech at the UNGA, 47th session, 1992; Christofias' speech at the ceremony of his investiture 2008) while President Papadopoulos perceives the Turkish Cypriots "as the real partners [...], in a condition of political equality vis-à-vis the state and the law" (speech at the official dinner given in his honour by the President of Greece, 2003). In this context, Turkey becomes the main culprit, but also the only one responsible for the suffering and plight of the Cypriot people.

\subsubsection{Comments}

The analysis of the social representations that the GCs have about the Cyprus conflict sheds light on the following research findings:

- trauma and victimization inform the GCs' social representations about the Cyprus conflict. The GCs' official discourses are built around Turkey's intervention in Cyprus in 1974 which they consider as being the most traumatic experience during the conflict yielding strong feelings of victimization;

- the nucleus of the social representations that the GCs have about the conflict consists of trauma and victimization. Furthermore, GCs' official discourses highlight only the experiences lived by the GCs as a consequence of Turkey's intervention, the emphasis being put only on one own's suffering;

- the constant reference to the 1974 episode and the Turkish intervention suggests a clinging to the past. The need to return to this moment in time and to this social context denotes the non-overcoming of the collective trauma, an unhealed past, the enduring nature of the losses, as well as the need for them to be recognised; 
- the GCs have built a discourse pattern about the conflict centred mainly on the Turkish "invasion" and "occupation" of the territory from Northern Cyprus, on the material and human consequences caused by Turkey's action, as well as on the status of being a victim. For GCs, the Cyprus conflict is a matter of occupation, invasion and aggression, where Turkey is the sole responsible for the grave situation Cyprus is faced with, and where understanding of what the conflict means or is about is done through the perspective of a victim status;

- The centrality of the 1974 episode in the official discourse on the Cyprus problem with focus on the unjust harm and the psychological wounds engendered has the "potential" to enhance polarization and pro-conflict attitudes among GCs, thus also impeding peace-making efforts.

\subsection{The representations that the TCs have about the Cyprus conflict}

For the analysis of the social representations that the TCs have about the Cyprus conflict, I have selected the following official speeches, official letters and interviews of the TC leaders: the speech of Rauf Denktash at the United Nations Security Council in November 1983; the letter dated 22 September 1996 sent by Rauf Denktash to the leader of the GCs, Glajkos Clerides; the interview given by Rauf Denktash to the journalists of a Turkish newspaper on 19 June 1999; the letter dated 31 May 2001 sent by Rauf Denktash to the United Nations; the letter dated 28 November 2008 sent by Mehmet Ali Talat to the United Nations; the letter dated 23 April 2010 sent by the leader of the TCs, Dervish Eroglu, to the United Nations Secretary General. These contain a holistic presentation of the Cyprus conflict from a TC perspective with emphasis on aspects related to trauma and victimization.

The TCs represent the conflict as being an internal problem between two politically equal communities, the GCs and the TCs. They invoke the London and Zurich accords from 1959 - 1960, which created the independent Republic of Cyprus and which established a bicommunal system which gave to the GCs and the TCs political equality. In the letter sent to the leader of the GCs, Glafkos Clerides, on 22 September 1996, Rauf Denktash emphasizes that "the crux of the 
inter-communal dispute is the attempt of the Greek Cypriot side to impose itself on us as "the Government of Cyprus" contrary to the Rule of Law and in complete disregard of the "state of affairs" created by the 1960 Treaties, which gave certain rights to each of the interested parties..." . According to the TCs, since the violent clashes between the two communities from 1963 due to the decision of the then GC leader, Makarios, to amend the constitution and remove certain TC rights, Cyprus has not been led by a single central administration:

"The partnership Republic of Cyprus, which was founded in accordance with international treaties, was in fact destroyed in 1963 by the Greek Cypriot partner's onslaught on the Turkish Cypriot partner, and there has not been a joint central administration in the island ever since. Each side has since ruled itself, while the Greek Cypriot side had continued to claim that it is the "Government of Cyprus". H ence, by late D ecember 1963 there was no longer an entity called "Republic of Cyprus" which reflected the 1960 A greements since one of the partners, namely Turkish Cypriots, were ousted by force of arms from all organs of the State and government" (excerpt from the latter dated 28 November 2008 sent by Mehmet Ali Talat to the United Nations).

The social representations that the TCs have about the conflict with the GCs can be translated into terms of "usurpation", "theft", "discrimination", "subjugation", and "domination". In his speech from November 1983 within the United Nations Security Council, Rauf Denktash, in reference to the situation of the TCs, emphasizes that "one part of a bi-communal government has been robbed by the other part of all its rights and has not given them back...". The same Rauf Denktash, in an interview given to a Turkish newspaper on 19 June 1999, illustrates the issue that Cyprus is being confronted with as being: "in essence, a problem of usurpation of administration. The Cyprus problem is an end product of the Greek Cypriot usurpation of the tile of "Cyprus government" by subjecting us for 11 years [from 1963 to 1974] to conditions that [Y ugoslavian President Slobodan] M ilosovic has done in Kosovo... The Cyprus problem is an end product of Greek Cypriot ambition to dominate us... to render us a minority by subjecting us 0 inhumane practices and by usurping our partnership in the state and sovereignty." 
In the same spirit, Mehmet Ali Talat, in the letter from 28 November 2008 addressed to the UN highlights "the Greek Cypriot usurpation of the Government since 1963". He also clarifies that the Cyprus problem started in 1963, and not in 1974, as the GCs claim, and that it is not a problem of occupation and invasion. Mehmet Ali Talat touches upon a subject that causes factions and deep disagreements between the two communities. Contrary to the GCs, the TCs assert that Turkey's involvement in the Cyprus conflict was legitimate and in accordance with the 1960 Treaty of Guarantee and that the only invasion on the island was that from Greece in 1974 through the junta coup attempt towards Makarios: "It is true that there had been an invasion on the island, but this is certainly not the Turkish intervention of 20 July, which is fully legitimate, as Turkey acted in accordance with her obligations under the 1960 Treaty of Guarantee. Rather, it is the Greek Cypriot usurpation of the Government since 1963 and Greek invasion of 15 July when the junta in A thens staged a coup on the island" (excerpt from the latter dated 28 November 2008 sent by Mehmet Ali Talat to the United Nations).

The TCs claim that Turkey, through its decision to intervene in 1974, saved them from "neutralization", "destruction" and "the conversion" of the partnership obtained through the 1960 accords into a "Greek Cypriot Republic". According to Rauf Denktash, if Turkey had not intervened the "Greek-Cypriots would have butchered us and solved the problem [... ] you would have driven us to the sea [... Even under the unbearable conditions, we kept on defending the Cyprus cause. We ever bowed, never surrendered. We always believed that one day Turkey would come and save us from all the difficulties we were pushed into. Turkey has come and saved us" (excerpt from Rauf Denktash's interview to a Turkish newspaper, 19 June 1999);

"Turkey had a right to rescue us and prevent the conversion of the partnership Republic into a Greek Cypriot Republic. But if Turkey moved in order to fulfil her obligation, then by the time Turkey arrived we would be "neutralized" in Cyprus [... ] M akarios wanted to abrogate the agreements so that Turkey would not have the right to intervene while he destroys the Turkish Cypriot community [...] The system prevented you from destroying us and from converting the island into a Greek Republic" (excerpt from Rauf Denktash' letter dated 22 September 1996 sent to the GC leader, Glafkos Clerides); 
"Turkey, as a guarantor Power, has protected and continues to protect the most basic human rights on the island and, thanks to Turkey, there has been no bloodshed in Cyprus for the past 27 years" (excerpt from Rauf Denktash's letter dated 31 May 2001 and sent to the United Nations). The same importance of the guarantee treaty from 1960 is also highlighted by Dervish Eroglu in the letter sent to the United Nations Secretary General, Ban Ki-moon, on 23 April 2010: "M oreover, the continuation of the 1960 system of guarantees [... ] is vital for the Turkish Cypriot side."

The temporal and contextual framing of the social representations TCs have about the conflict is marked by the period of time between 1963 and 1974, when they had to live in enclaves in very harsh conditions. For the TCs, this moment and social context represent a collective trauma that generates painful memories of the suffering that they were submitted to and feelings of victimization and humiliation. From the above excerpts, it can be noticed the presence of words such as "inhumane", "unbearable" or "difficult" that the TCs use in describing the 1963 - 1974 period: "inhumane practices", "unbearable conditions", "all the difficulties we were pushed into". Other types of expressions used by the TCs in describing the same period are: "the indignities and harassment of the 1963-1974 period", "atrocities", "massacres", "tragedies", "the horrendous nature of the events between 1963-1974", "ill treatment" (excerpt from Rauf Denktash' letter dated 22 September 1996 sent to the GC leader, Glafkos Clerides); "unjust and inhuman isolations", "inhuman restrictions", "veritable siege" (excerpt from Mehmet Ali Talat' letter dated 28 November 2008 and sent to the United Nations). The eleven years that the TCs refer to in the official discourses as well as the types of expressions used in describing these years, suggest suffering, pain and distress. During this period, TCs were crowded in enclaves, which covered only $3 \%$ of the island, and surrounded by three lines of soldiers belonging to the United Nations, TC and GC communities (Bryant 2012, 7). According to Rauf Denktash, the GCs "forced" TCs "out of 103 villages and locked us in 3\% of the island" (excerpt from the interview Rauf Denktash gave to a Turkish newspaper, 19 June 1999). Within the enclaves, TCs endured harsh conditions, "inhuman" as the TC leaders constantly repeat in their discourses, including limited housing, food and other material shortages. The TC people lived in tents, caves, and warehouses while 
being practically imprisoned in the enclaves and, until 1968, they lived in isolation without any access to their homes, lands or the possibility to visit other enclaves (Volkan 2008, 96-97). They have been subjected to "overwhelming stress and change" and became "victims of the massive psychic trauma of expulsion from their homes, the loss of many dear to them, and constant fear" (Volkan 1979, 81).

The selected official discourses of TC leaders speak about a community which suffered many years of difficulties, annihilation anxiety and isolation, and which felt oppressed at the hand of GCs. They refer to the TCs humiliation and dehumanization inflicted by GCs, and to the many human rights deprivations they suffered during the years living in the enclaves (Volkan 2008, 97-98). The feeling of being victimized among the TCs is entirely attributed to the GCs due to the traumatic experiences lived between 1963 - 1974. The GCs appear as guilty of the sufferings endured by the TCs, while the latter consider themselves as the victims of the GCs. This victimization feeling was formed in the course of a long period of conflict, and as a result of the loss and damage suffered by TCs. In the official discourses, the TCs' references to the 1963 - 1974 period contain also descriptive elements that come in the support of their claims regarding the sufferings as well as the violence they were submitted to, and indicate the viciousness of GCs acts towards them. For instance, in the letter dated 22 September 1996 and addressed to the GC leader, Glafkos Clerides, Rauf Denktash inserts what he names "cleansing operations" "mercilessly" directed by the GCs against the TCs, and describes in detail the manner in which the GCs attacked and killed TCs people, no matter the age or sex:

"Even sixteen-day old babies, 1, 2, 3, year olds were not spared. 80-90 years old people were mercilessly gunned down [... ] elementary school-children lined up and shot [...] I enclose for your eyes the pictures of mass graves in Ayios Vasilios where in December 1963 the Turkish Cypriot civilians (women and children, old men and women) were taken from their homes, lined up and shot. The number of Turkish Cypriots killed and wounded and the missing during 1963-1974 runs into several thousands." 


\subsubsection{Comments}

The analysis of the social representations that the TCs have about the Cyprus conflict sheds light on the following research findings:

- trauma and victimization influence the forming of the TCs' social representations about the Cyprus conflict. The official discourses of the TCs are built around the collective trauma caused by the "inhumane practices", "unbearable conditions" and the "veritable siege" that took place between 1963 1974 and the victimization generated at the collective level by this traumatic period;

- the trauma and victimization at the collective level caused by the sufferings, torment and injustices that happened between 1963 - 1974 constitute the central part of the social representations that the TCs have about the conflict. This period of eleven years represents a reference point which is profound (because it encapsulates all the endured abuses and injustices) and acute (because the suffering is still ongoing);

- the construction of the social representations that the TCs have about the conflict by resorting to the traumatic experiences and sufferings associated with the 1963 - 1974 period suggests a strong connection to the past, the persistence of the traumatic memories and the need for the recognition of the endured sufferings;

- the TCs' official discourses about the conflict follow a pattern mainly focused on the plight of the TCs who seen themselves as victims of GCs perceived to be the main responsible for the sufferings endured along the conflict, especially between 1963-1974, and for the situation they are encountered in the present;

- the repetitive references of the 1963-1974 period that invokes in the TCs feelings of humiliation and victimization by GCs, the blame and the recall of what the enemy has committed in the past accentuate the divide, promotes conflict and blocks the opening towards co-existence or future collaboration with GCs. 


\section{CONCLUSIONS}

The Cyprus conflict is an intractable conflict that has been on the agenda of the international community for more than five decades, has gone through sporadic episodes of violence and had resisted to the multiple efforts of resolve laid down by third parties. The research approach of this paper attained its objectives, namely it highlighted the interdependent relationship between social representations, trauma, and victimization in the Cyprus conflict as well as the connection between them and the perpetuation of this conflict.

Firstly, the two communities have developed different social representations about the conflict they are involved in. For the GCs, the conflict is a matter of foreign occupation, aggression and invasion linked to Turkey's decision to militarily intervene on the territory of Cyprus in 1974. For the TCs, the conflict is an inter-communal strife between two politically equal communities, which began in 1963 with the decision of the then GC leader, Makarios, to amend the constitution and try to outpower the TC community. Thus, one can notice the existence of certain fundamental differences in interpretation of the same historical events, leading to a collision between the two parties' official discourses.

Secondly, the leaders of the two communities emphasize two different moments of time and social contexts as being the most traumatic experiences that they went through during the conflict. The GCs focus on the year of 1974, the month of July, which marks Turkey's military intervention in Cyprus, while the TCs focus on the 1963 - 1974 period, which marks some long-lasting eleven years of living in enclaves in isolation, deprivation and harsh conditions. These represent turning points for the trajectories of the two communities and form collective traumas, engendering strong feelings of victimization. Furthermore, one can notice two opposing official discourses about the conflict where each party choose to remember and emphasize only its own suffering, with little regard towards the other's own pain, thus constructing what Maria Hadjipavlou (2009, 26) calls on her writings an "ecliptic reality".

Thirdly, collective trauma and victimization lie central to the way in which each party represents the conflict. The prioritization of these two aspects in the 
emotional official discourses of GCs and TCs about the Cyprus conflict suggests the impossibility to detach from these traumatic experiences, the strong orientation toward the unhealed past, the importance the parties attach to the past and its domination over the present as well as the need for the pain to be recognized. Also, the collective past traumas seem to obscure the parties' ability to acknowledge the grievances of the "other". The analysis of the official discourses indicates a lack of recognition of each other's collective traumas from both parties. They remain bound to the injustices inflicted by the "other" concentrate only on their own traumas and sufferings, do not make any references to the traumatic events experienced by the adversary, thus contributing to the deepening of divisions between them.

Fourthly, the different social representations that the GCs and the TCs have about the conflict are influenced by the collective past traumas and by victimization. The latter constitute a "central nucleus" (Abric 1994a) of the two parties' social representations of the conflict that petrifies in the face of a continued lack of resolve. Moreover, the social representations that are thus formed bring back into discussion the traumatic past experiences and the sense of victimization. This is why each replay of the traumatic events in the official discourses of the two parties (the Turkish invasion from July of 1974 for the GCs, and respectively the 1963 - 1974 period and the living in enclaves, in isolation, for the TCs) remakes the original sense of the trauma topical and reinforces the collective feeling of victimization of the two communities. Hence, what results is an interdependent relationship between social representations, trauma and victimization as well as the manner in which they mutually determine each other.

Fifthly, the role that trauma and victimization hold in forming the social representations of the GCs and TCs about the conflict, as well as the function had by the social representations that are thus formed, namely of remaking and reinforcing the trauma and the feeling of victimization topical, determine the perpetuation of the Cyprus conflict. In the dynamic of this conflict, the social representations, the trauma and the victimization are important components, with a content that is rich value-wise and information-wise. They support the divide between the GCs and the TCs, cultivate a culture of separation, deepen 
the "us" and "them" dichotomy, thus also hindering the settlement's efforts. In other words, they are acting as blockages to peace. As resulted from the analysis of the GCs and TCs' official discourses, these are competitive, based on an adversarial model, implying the conflict is not seen as a shared problem to settle. They do not seem to promote a pro-solution culture, rather fortifies pro-conflict attitudes, polarization, animosity by always pointing the other's guilt and using the victimhood argument.

The research findings illustrate a mutually reinforcing relationship between social representations, trauma and victimization which negatively influence the settlement of the Cyprus conflict. Furthermore, they highlight the importance that these psychosocial factors have in the dynamics of the Cyprus conflict and contribute to a better understanding of its essence. In turn, such an understanding could also offer a path towards the further development of a more efficient formal peace process.

\section{REFERENCES}

- Abric, Jean-Claude. 1994a. "Les représentations sociales: aspects théoriques." In Pratiques sociales et representations, edited by Jeav-Claude Abric, 11-35. Paris: Presses Universitaires de France.

- $\quad$ Anastasiou, Maria.2007. "The Institutionalization of Protracted Ethnic Conflicts: A Discourse Analysis of "The Cyprus Problem"." PhD diss., University of South Carolina.

- $\quad$ Azar, Edward E. 1990. The M anagement of Protracted Social Conflict: Theory and Cases. Aldershot, Hampshire, England: Dartmouth.

- $\quad$ Bar-Tal, Daniel, Lily Chernyak-Hai, Noa Schori and Ayelet Gundar. 2009. "A sense of self-perceived collective victimhood in intractable conflicts." International Review of the Red Cross, 91 (874): 229-258.

- Bar-Tal, Daniel. 2007. "Sociopsychological Foundations of Intractable Conflicts." A merican Behavioral Scientist, 50 (11): 1430-1453.

- $\quad$ Bar-Tal, Daniel. 2013. Intractable Conflicts: Socio-Psychological Foundations and D ynamics. Cambridge, UK: Cambridge University Press.

- Bar-Tal, Daniel. 2014. "Collective memory as social representations." Papers on Social Representations, 23: 5.1-5.26. 
- Bar-Tal, Daniel, Eran Halperin, Ruthie Pliskin. 2014. "Why Is It So Difficult To Resolve Intractable Conflicts? A Sociopsychological Explanation." In $\mathrm{H}$ andbook of International Negotiations: Interpersonal, Intercultural, and Diplomatic Perspectives edited by Mauro Galluccio, Switzerland: Springer.

- $\quad$ Brewer, Marilynn. 2011. "Identity and Conflict." In Intergroup Conflicts and Their Resolution. A Social Psychological Perspective, edited by Daniel Bar-Tal, 125-143. New York: Psychology Press Taylor \& Francis Group.

- Bryant, Rebecca. 2012. Displacement in Cyprus. Consequences of Civil and Military Strife. Report 2. Life Stories: Turkish Cypriot Community, PRIO Cyprus Centre. http://www.prio-cyprusdisplacement.net/images/users/1/Report\%202-\%20R.BRYANT\%20ENGWEB.pdf

- $\quad$ Burton, John. 1987. Resolving Deep-Rooted Conflict: A H andbook. Lanham MD: University Press of America.

- Coleman, Peter. 2006. "Intractable Conflict." In The H andbook of Conflict Resolution. Theory and Practice, edited by Morton Deutsch, Peter Coleman and Eric Marcus, 533-559. San Francisco: Jossey-Bass.

- Deutsch, Morton. 1985. Distributive Justice: A Social Psychological Perspective. New Haven: Yale University Press.

- $\quad$ Erikson, Kai. 1995. "Notes on Trauma and Community." In Trauma: Explorations in Memory, edited by Cathy Caruth, 183-200. Baltimore: John Hopkins University Press.

- Fisher, Ronald J. 2001. "Cyprus: The Failure of Mediation and the Escalation of an Identity-Based Conflict to an Adversarial Impasse." Journal of Peace Research, 38 (3): 307-326.

- $\quad$ Fisher, Ronald J., and Herbert C. Kelman. 2011. "Perceptions in Conflict." In Intergroup Conflicts and Their Resolution. A Social Psychological Perspective, edited by Daniel Bar-Tal, 61-81. New York: Taylor and Francis Group.

- Friedman, Matthew J. 2016. "PTSD History and Overview". PTSD: National Center for PTSD, U.S. Department of Veterans Affairs. https://www.ptsd.va.gov/professional/ptsd-overview/ptsd-overview.asp

- Goertz, Garry and Paul F. Diehl.1993. "Enduring rivalries: Theoretical Constructs and Empirical Patterns." International Studies Quarterly, 37 (2): 147171.

- Gross Stein, Janet. 1996. "Image, Identity and Conflict Resolution." In $\mathrm{M}$ anaging Global Chaos, edited by Chester Crocker, Fen Hampson and Pamela Aall, 93-111. Washington, D.C.: United States Institute of Peace Press. 
- Hadjipavlou, Maria. 2007. "The Cyprus Conflict: Root Causes and Implications for Peacebuilding." J ournal of P eace R esearch, 44 (3): 349-365.

- Hadjipavlou, Maria. 2009. "Reconciliation in Protracted Conflict. The Cypriot experience from the non-governing elite perspective". Paper presented at the International Society of Political Psychology 32 ${ }^{\text {nd }}$ Annual Meeting, Trinity College Dublin, July 14-17.

- Hadjipavlou, Maria. 2017. "The "Crossings" along the Divide: the Cypriot Experience." In The Walls between Conflict and Peace, edited by Alberto Gasparini, 197-216. Leiden: Brill.

- Hadjipavlou-Trigeorgis and Leon Trigeorgis. 1993. "An Evolutionary Approach to Conflict Resolution." The Journal of Conflict Resolution, 37 (2): 340360.

- $\quad$ Hunter, Andrea K., and Abigail J. Stewart. 2015. “Past as Prologue: How History Becomes Psychologically Present." Journal of Social Issues, 71 (2): 219-228.

- Kelman, Herbert. 2007. "Social-Psychological Dimensions of International Conflict." In Peacemaking in International Conflict. M ethods and Techniques, edited by I. William Zartman, 61-107. Washington, D.C.: United States Institute of Peace.

- Kriesberg, Louis. 2005. "Nature, Dynamics, and Phases of Intractability." In Grasping the N ettle. A nalyzing Cases of Intractable Conflict, edited by Chester A. Crocker, Fen Osler Hampson, and Pamela Aall, 65-97. Washington, D.C.: United States Institute of Peace Press.

- $\quad$ Küçükkoşum, SEVİL. 2010. “Turkish Cypriot leader ready for tripartite New York meeting." Hürriyet Daily News, October 22, 2010. http:/ / www.hurriyetdailynews.com/turkish-cypriot-leader-ready-for-tripartitenew-york-meeting.aspx?pageID $=438 \& n=$ turkish-cypriot-leader-ready-for-unchief8217s-call-tripartite-meeting-2010-10-22

- Mack, John, 1990. "The Enemy System." In The Psychodynamics of International Relationships. Vol. I: Concepts and Theories, edited by Vamik D. Volkan, Julius A. Demetrios and Joseph V. Montville, 83-95, Lexington, MA: Lexington Books.

- $\quad$ Michael, Michális, 2009. Resolving the Cyprus Conflict. N egotiating History. New York: Palgrave Macmillan.

- $\quad$ Mohatt, Nathaniel V., Azure B. Thompson, Nghi D. Thai, and Jacob K. Tebes. 2014. "Historical trauma as public narrative: A conceptual review of how history impacts present-day health." Social Science \& M edicine, 106: 128-136. http:/ / doi.org/10.1016/j.socscimed.2014.01.043 
- Morelli, Vincent L. 2015. Cyprus: Reunification Proving Elusive. Congressional Research Service Report:1-37. https:/ / fas.org/sgp/crs/row/R41136.pdf on 15/03/2017

- Morris, Harvey. 2010. "Parties in Cyprus dispute agree more UN talks." Financial Times, November 19, 2010. https://www.ft.com/content/94ddc47af342-11df-a4fa-00144feab49a

- Noor, Masi Nurit Shnabel, Samer Halabi, Arie Nadler. 2012. "When Suffering Begets Suffering." Personality and Social Psychology Review, 16 (4): 351 374.

- $\quad$ Security Council Report. 2008. "Cyprus: New Hope After 45 Years On The Security Council Agenda", no. 3. September 4, 2008. http:/ / www.securitycouncilreport.org/atf/cf/\%7B65BFCF9B-6D27-4E9C-8CD3CF6E4FF96FF9\%7D/Research\%20Report\%20Cyprus\%204\%20Sep\%2008.pdf

- $\quad$ Souter, David. 1989. "The Cyprus Conundrum: The Challenge of the Intercommunal Talks." Third W orld Q uarterly, 11 (2): 76-91.

- Staub, Ervin. And Daniel Bar-Tal. 2003. "Genocide, mass killing and intractable conflict: Roots, evolution, prevention and reconciliation." In Oxford $\mathrm{H}$ andbook of Political Psychology, edited by David O. Sears, Leonie Huddy, Robert Jervis, 710-751. New York: Oxford University Press.

- Theophanous, Andreas and Odysseas Christou. 2014. "The Cyprus Question and the Role of the UN: An Overall Assessment." The Journal of M odern H ellenism, 30: 73-89. http://journals.sfu.ca/jmh/index.php/jmh/article/view/7

- $\quad$ Tint, Barbara. 2010. "History, Memory, and Intractable Conflict." Conflict Resolution Quarterly, 27 (3):239-255.

- United Nations Secretary-General. 2004. The Comprehensive Settlement of the Cyprus Problem, March 2004. http:/ / www.hri.org/docs/annan/Annan_Plan_April2004.pdf

- United Nations Security Council. 2004. Report of the Secretary-General on his mission of good offices in Cyprus, May 28, 2004. http:/ / www.un.org/en/ga/search/view_doc.asp?symbol=S/2004/437

- United Nations Security Council. 1964. Resolution 186, The Cyprus Question, March

4 , 1964. http:/ / www.un.org/en/ga/search/view_doc.asp?symbol=S/RES/186(1964) - United News Centre. 2012. Cyprus: Ban calls for decisive steps towards final settlement after intensive talks, 25 January 2012. http:/ / www.un.org/apps/news/story.asp?NewsID=41035\#.WRtEp8b-vIX 
- United News Centre. 2011. Cyprus: leaders agree to intensify reunification talks after meeting with Ban, 26 January 2011. http://www.un.org/apps/news/story.asp?NewsID=37386\#.WRtDIMb-vIV

- United News Centre. 2011. Deal between Greek Cypriot and Turkish Cypriot leaders is attainable - Ban, 1 November 2011. http://www.un.org/apps/news/story.asp?NewsID=40271\#.WRtEc8b-vIX

- $\quad$ United News Centre. 2017. Greek Cypriot and Turkish Cypriot leaders agree to greater UN role in talks - Ban, 7 July 2011. http://www.un.org/apps/news/story.asp?NewsID=38967\#.WRtEAMb-vIX

- Volkan, Vamik D. 1998. Bloodlines: From Ethnic Pride to Ethnic Terrorism. Boulder, CO: Westview Press.

- Volkan, Vamik D. 2008. “Trauma, Identity and Search for a Solution in Cyprus." Insight Turkey, 10 (4): 95-110.

- Volkan, Vamik D. 1979. Cyprus - War and Adaptation. A Psychoanalitic History of Two Ethnic Groups in Conflict. Charlottesville: University Press of Virginia.

- Wertsch, James V., and Henry L. Roediger, H. III. 2008. "Collective memory: Conceptual foundations and theoretical approaches." M emory, 16 (3): 318-326.

- $\quad$ Sources for the selected speeches of GCs leaders:

- $\quad$ President Vassiliou's speech at the 47th session of the UNGA, 1992. Available at http://www.un.org/ga/search/view_doc.asp?symbol=A/47/PV.7

- $\quad$ President Clerides' speech at the 54th session of the UNGA, 1999. Available

http://www.un.org/ga/search/view_doc.asp?symbol=A/54/PV.10

- President Papadopoulos' inaugural speech at the House of Representatives, $2003 . \quad$ Available at http://www.piopressreleases.com.cy/easyconsole.cfm/page/search

- $\quad$ President Papadopoulos' speech during an official visit to Greece, 2003. Available http://www.piopressreleases.com.cy/easyconsole.cfm/page/search

- $\quad$ President Papadopoulos' speech at the 62nd session of the UNGA, 2007. Available at http://www.un.org/ga/search/view_doc.asp?symbol=A/62/PV.7

- $\quad$ President Christofias' speech at the ceremony of his investiture at the special session of the House of Representatives, 2008. Available at http://www.piopressreleases.com.cy/easyconsole.cfm/page/search 
- $\quad$ President Christofias' speech at the 66th session of the UNGA, 2011. Available http://www.un.org/ga/search/view_doc.asp?symbol=A/66/PV.15

- $\quad$ President Christofias' speech at the 67th session of the UNGA, 2012. Available http://www.un.org/ga/search/view_doc.asp?symbol=A/67/PV.6

- $\quad$ Sources for the selected speeches, letters and interviews of TCs leaders: - Speech of Rauf Denktash at the United Nations Security Council, November 1983. Available at https:/ / www.youtube.com/watch?v=Couo4LeSP88

- $\quad$ Letter dated 22 September 1996 sent by Rauf Denktash to the leader of the GCs, Glajkos Clerides. Available at http://www.mfa.gov.tr/letter-sent-bytrnc-president-rauf-denktas-to-the-greek-cypriot-leader-glafkos-clerides_-22september-1996.en.mfa

- Interview given by Rauf Denktash to the journalists of a Turkish newspaper on 19 June 1999. Available at http:/ / www.hurriyetdailynews.com/exclusive-interview-with-president-raufdenktas-of-the-turkish-republic-of-northerncyprus.aspx?pageID $=438 \& n=$ exclusive-interview - with-president-rauf-denktasof-the-turkish-republic-of-northern-cyprus-1999-06-19

- $\quad$ Letter dated 31 May 2001 sent by Rauf Denktash to the United Nations. Available at http:/ / www.un.org/documents/ga/docs/55/a55986.pdf

- $\quad$ Letter dated 28 November 2008 sent by Mehmet Ali Talat to the United Nations. Available at http://repository.un.org/bitstream/handle/11176/11909/A_63_578\%3BS_2008 _749-EN.pdf?sequence $=23$

- $\quad$ Letter dated 23 April 2010 sent by Dervish Eroglu to the United Nations. Available at http://kiatipis.org/cyprus_problem_eng/postings/2010-0423_D.Eroglu.htm 